\title{
Children Friendship: The Role of Hope in Attributions, Emotions and Expectations
}

\author{
Georgia Stephanou \\ Department of Early Childhood Education, University of Western Macedonia, Florina, Greece \\ Email: gstephanou@uowm.gr, egokesy1@otenet.gr \\ Received August 24 $4^{\text {th }}, 2011$; revised September 27 ${ }^{\text {th }}, 2011$; accepted October $28^{\text {th }}, 2011$.
}

\begin{abstract}
This research aimed to examine 1) children's attributions and emotions for their subjectively perceived friendships with their best friends as positive or negative, 2) the role of children's hope (pathways thinking, agency thinking) in the generation of their perception of their friendships as positive or negative, in the formulation of the subsequent attributions and emotions, and in the impact of attributions on emotions, and 3) the effects of hope in the interactive impact of attributions and emotions on friendship expectations. The participants were 322 children, both gender, 5th and 6th grades, representing various parental socioeconomic levels. The results showed that the perceived satisfactory friendships were mainly attributed to internal, and self-friend interactive internal and controllable factors, while the estimated as non satisfactory friendships were predominately attributed to stable, friend's controllable and internal, and self-friend interactive internal factors. The children experienced intense positive and negative emotions for their perceived satisfactory and non satisfactory friendships, respectively. Hope (mostly, agency thinking) positively influenced the generation of the perceived quality of the friendship, the subsequent attributions (particularly, stability) and emotions, and the impact of attributions on emotions, mainly in the negative friendships group. Also, in the positive friendship group, high-pathway thinking children had higher expectations of positive friendship, whereas, in the non satisfactory friendship group, low-agency thinking children had low expectations of positive friendship. Finally, hope proved formulator of the interactive effect of attributions (mainly, locus of causality) and emotions on friendship expectations. The findings from this study suggest the significant role of good friendship in children's life, and indicate the importance of examining children friendship along the role of hope in evaluating, attributing causes, experiencing emotions and forming expectations.
\end{abstract}

Keywords: Attributions, Emotions, Expectations, Hope, Perceived friendship

\section{Introduction}

Within the broad domain of youth relationships, kinship, cooperation with peers and close friendship are related to enduring happiness and well-being (Argyle, 2001; Berndt, 2004; Carr, 2005; Holder, \& Coleman, 2009; Vandell, Nenide, \& Van Winkle, 2007). Focusing on children friendships with their best friends, in particular, may contribute into enhancing their happiness and subjective well-being, as positive psychology conceptualizes (Aspinwall \& Staudinger, 2003; Diener, Lucas \& Oishi, 2005; Myers, 2000; Roberts, Brown, Johnson, \& Reinke, 2005; Seligman, 2002, 2005). Furthermore, understanding their perceptions of friendships may help understand their emotional lives and development, since happy young people are those who report fulfilling friendships (Bukowski, 2001; Buss, 2005; Diener, 2000; Diener \& Seligman, 2002; Flecher \&Thomas, 1996; Hoglund, Lalonde, \& Leadbeater, 2008).

Cognition and cognitive process are significant contributors in the development and quality of a close relationship, and so need to be considered in any comprehensive investigation of friendship (Blas, 2007; Harvey, Pauwels, \& Zickmund, 2005; Karney, McNulty, \& Bradbury, 2003). Intuitive and atributional appraisals are two such constructs which have been central concepts examining close relationships (Collins, Ford, Guichard, \& Allard, 2006; Fincham, 2003; Greitemeyer, \& Weiner, 2003; Harvey, 1987; Harvey \& Omarzu, 1999; Prager, 1995; Reis, \& Patrick, 1996; Stephanou, 2004, 2005; Weiner, 2000). Whether partners perceive their relationship as positive or negative, and which explanations or interpretations they make about the relationship influence their emotions, motivation and be- haviour (Blascovich \& Mandess, 2000; Flecher, Fitness, \& Blampied, 1990; Flecher \& Thomas, 2000; Fincham, 2003; Fincham, Beach, Arias, Brody, 1998; Fitness, Fletcher, \& Overall, 2005).

Similarly, emotions are inherently and intensely experienced in the context of close relationships, theyplay important role in future behaviour, and so they are needed to be included in any comprehensive discussion (Baucom, Epstein, Stanton, 2006; Berscheid, \& Ammazzalorso, 2003; Forgas, 2002; Forgas, \& Smith, 2005; Parrott, 2003; Rose, 2007; Siemer, Mauss, \& Gross, 2007; Smith, \& Kirby, 2000). The attributional appraisal perspective to emotions focuses on how specific emotions such as sadness and anger are elicited, and on the motivational functions they serve in particular relationship (Clore, \& Ortony, 2010; Frijda, 1993, 2007; Smith, \& Kirby, 2000; Weiner, 2002, 2005). For example, if one believes that the friend's good behaviour was the significant factor for their good friendship, then she/he may experience admiration or gratitude. Anger combines distress over an undesired event with perceiving the other as responsible for it (Ortony, Clore, \& Collins, 1988). Once emotions are experienced, they influence partners' on-going appraisals, perceptions, information processing with important consequences in relationship judgments and behaviours (see Bless, 2003; Parrott, 2003, Weiner, 2006). For example, happy partners make more optimistic attributions than unhappy (Forgas, 1994; Planalp \& Fitness, 1999). Anger pushes individuals to attribute blame and malicious intentions to others (Fitness \& Fletcher, 1993; Keltner, Ellsworth, \& Edwards, 1993).

As the friendship develops, then, the friends are forming expectations for a series of constructs in the relationship such as 
the friend dispositional behaviour and the content of the friendship. Researches in the person perception and cognition underline that the dispositional attributions an individual makes to the partner reflects an expectations of how he/she will behave in various situations (see Berscheid, \& Ammazzalorso, 2003; Karney et al., 2003; Trope, \& Gaunt, 2005). The expectations we hold about our friend and the friendship are partly constructed through the cognitive appraisals we make and the emotions we experience in the friendship (Bigelow, 1997; Forgas, \& Smith, 2005; Stephanou, \& Balkamou, 2010). Similar are the findings from research in achievement behaviour showing the high expectations for success are related to task engagement, persistence in carrying out tasks, effective use of cognitive and metacognitive strategies, and successful performance (see Eccles, \& Wigfield, 2002; Efklides, 2001; Stephanou, 2008).

On the other hand, as mentioned by Siegel (1992), 'individual differences factors can influence both a child's responses to stress and his or her use of coping strategies' (p. 4). Further, as was indicated by Siegel and supported by respective research, children tend to respond to daily life stimuli by using the same mechanism of responding to stress (see for a review Roberts et al., 2005). Additionally, there is an increasing recognition that a comprehensive conceptualization of coping mechanisms views them as normal developmental components (Carr, 2005; Dryfoos, 1998; Jaycox, Reivich, Gilhan, \& Seligman, 1994). Hope, as it is conceptualized in Snyder's $(1994,2005)$ hope theory, is a significant construct in understanding how children deal in friendships (Smith \& Kirby, 2000; Snyder, Cheavens, \& Sympson, 1997). Researches (e.g., Snyder, Hoza, Pelham, Rapoff, Ware, Danovsky, Highberger, Rubinstein, \& Stahl, 1997; Snyder, McDermott, Cook, \& Rapoff, 1997; Stephanou, 2010) have shown that the majority of children are able to use hopeful, goal-directing thought. In middle childhood and preadolescence, in particular, there is a growth in logical rather than intuitive thinking skills, which contributes to increasing hopeful planning and pursuing pathways towards value-goals and doing so within a social context of mindful of the wishes of significant others, including peers and friends (Carr, 2005; Snyder, 2000).

Hope influences how children interpret and feel in close relationships (Roberts et al., 2005; Stephanou, 2010). Specifically, although in hope theory the focus is on reaching desired future goal-related outcomes, hope is related to attributions for past behaviour, since both theories elaborate pursuit goals and important outcomes (see Seligman, 1991; Snyder, Rand, \& Sigmon, 2005; Weiner, 2002). Hope is related to emotions in a given close relationship, since goal-pursuit cognitions, such as avoiding or alleviating harm or maximizing benefits in it cause emotions (Smith \& Ellsworth, 1987; Snyder et al., 2005).

Moreover, 'the goal of 'conecting' with other people is fundamental because the seeking of one's goals almost always occurs within the context of social commerce' (Snyder et al., 2005 , p. 266). People with high hope enjoy high social desirability, perceive social support, are not characterized by loneliness, enjoy their interactions with others, and are socially competent (Barnum, Snyder, Rapoff, Mani, \& Thompson, 1998; Snyder, Hoza et al., 1997; Sympson, 1999). Generally, individuals with high dispositional hope enjoy life, and use positive reappraisal for a variety of stressor situation, and they not use avoidance and denial behaviour (Gilham, 2000; Snyder, 2000; Snyder, Cheavens, \& Michael, 1999).

However, only a limited number of studies have focused on children's friendships (see Bukowski, 2001; Gifford-Smith \& Brownell, 2003; Hoglund et al., 2008; Rose, 2007; Stephanou \& Balkamou, 2010; Vandell et al., 2007), on children's hope, attributions and emotions for their friendships, and on how these concepts interactively influence friendship expectations (see Bowker, Rubin, Burgess, Booth-LaForce, \& Rose-Krasnor, 2006; Fincham, 2003; Jenkins, \& Ball, 2000; Lewis, \& Kliewer, 1996; Overwalle, Heylighen, Casaer, \& Daniels, 1992; Rockhill, Fan, Katon, McCauley, Crick, \& Pleck, 2007; Stephanou, 2010; Underwood, \& Hurley, 1999).

Accordantly, this study is based on the connection between friendships and emotional experience from a socio-cognitive perspective. Specifically, Weiner's $(1992,2001,2002)$ attributions theory was involved, which, incorporating cognitive appraisals and emotions, is helpful in understanding interpersonal relationships, (see Argyle, 2001; Fincham, 2003; Fitness et al., 2005; Fletcher, \& Clark, 2003; Hewstone, \& Antaki, 2001). Snyder's (2000) hope theory was also used, which, incorporating waypower and willing power, offers an important construct in understanding how children deal and interact with others (Roberts et al., 2005).

\section{Attributions and Emotions for Interpersonal Relationships}

Individuals appraise an interpersonal relationship by evaluating and by attributing causes (Leary, 2000; Smith, \& Lazarus, 1990; Trope, \& Gaunt, 2005). The appraisals reflect what the stimulus-relationship means to the individual and whether it is good or bad (Fincham, 2003; Fitness et al., 2005).

Although, an interpersonal relationship could be attributed to infinite number of attributions, self, other person, situation, environment, self-other person interaction, and relationship itself are the most prominent causes in describing positive and negative relationships (Argyle, 2001; Erber, \& Gilmour, 1995; Planalp, \& Rivers, 1996). Attributions are categorized into dimensions of locus of causality (internal /external to the person), stability (stable/unstable over time) and controllability (personal and external controllable/uncontrollable), which have psychological and behavioral consequences (Argyle, 2001; Berscheid, \& Ammazzalorso, 2003; Fletcher \& Thomas, 2000; McAuley, Duncan, \& Russell, 1992; Stephanou, 2005, 2007; Weiner, 2002, 2005).

The perceived quality of the relationship differentiates the attributional pattern (Fiedler, Semin, Finkenauer, \& Berkel, 1995; Fincham, 2003). Specifically, individuals tend to attribute the positive interpersonal relationships to themselves (internal, stable, personal controllable, and external uncontrollable), and the negative relationships to the other person and situational factors (Fitness et al., 2005; Stephanou, 2005, 2007; Weiner, 2001, 2002; Ybarra \& Stephan, 1999). Furthermore, the more negative the interpersonal relationship the more the attributions to the other person's constant negative properties (Argyle, 2001; Gilbert \& Malone, 1995; Hewstone \& Antaki, 2001; Williams \& Gilmore, 2008).

Previous researches show that both intuitive appraisal and the attributional appraisal are major source of experienced emotions in interpersonal relationships (Clark, Fitness, \& Brissette, 2003; Fletcher, 2002; Smith, \& Lazarus, 1990; Trope \& Guant, 2005; Weiner, 2002). According to Weiner's (2002) attribution theory, in particular, there are 'outcome- dependent' (e.g., happiness, pleasure, sadness) emotions, that are the initial and strongest response to the valence of the relationship. For example, if it is positive, a person fells happy, whereas if it is negative, he/she fells sad. The 'attribution-dependent' (e.g., anger, encouragement) emotions are influenced by the causal explanation for the relationship (Oatley, \& Jenkins, 1998; Stephanou, 
2007; Weiner, 2002). For example a child may experience anger if believes that the friend could and should have behaved differently. In contrast, a child may feel confidence if she/he considers the friend's positive dispositional factors as causes for the positive friendship.

Although all causal dimensions are related to emotions for the partner's (friend) behavior and the relationship itself, their prevalence differs across the various emotions. Locus of causality, stability and controllability mainly influences the selfesteem (pride)- expectancy (confidence)- and social (shame, anger, gratitude)-related emotions, respectively (Berndsen, \& Manstead, 2007; Stephanou 2007; Weiner, 2005, 2006). For example, internal attributions for successful events (positive friendship) is related to feelings of confidence and pride, whereas external attributions leads to positive behaviors such as help seeking, or negative responses, such as helplessness, avoidance and lack of persistence. In contrast, attributing unsuccessful events (negative friendship) to internal factors predicts incompetence, shame, guilt and resignation, whereas attributing unsuccessful events to others causes aggression and vindictiveness (see Fincham, 2003; Fitness et al., 2005).

Attributing successful relationship to stable factors enhances relationship expectations, and facilitates relationship engagement, while attributing negative friendship to unstable is likely to improve friendship and minimizes the feeling of hopelessness. In contrast, attributing negative relationship to stable factors reduces positive expectations, produces the feeling of hopelessness and can lead to learned helplessness, a sense that none effort can lead to good friendship (see Fitness et al., 2005; Peterson and Steen, 2005; Seligman, 2002; Weiner, 2001).

Guilt and anger are elicited by controllable causes, but guilt emerges from internal, whereas anger is elicited by external factors (Stephanou, 2007, 2010; Weiner, 1992). Hate resulted from appraisals of relative powerlessness and a perceived lack of control (see Fitness et al., 2005). Also, stable causes maximize feelings of pity, given uncontrollable causes, and feelings of anger, given controllable causes (Graham, \& Hoehn, 1995).

Overall, the belief that a person has about the causes of his/ her friendship have effects on his/her feelings for the friend, and his/her expectations for the quality of the friendship in the future (Clark et al., 2003; Fletcher, 2002; Siemer et al., 2007; Stephanou, \& Balkamou, 2010; Weiner, 2001). Then, emotions and expectations influence the individual's actual behavior toward the partner, and the friendship itself (see Fincham, 2003; Fletcher, \& Clark, 2002, Fletcher, \& Thomas, 2000; Weiner, 2001).

\section{The association of Hope with Attributions, Emotions and Expectations}

According to Snyder's (see Snyder et al., 2005) hope theory, hope is a cognitive set including an individual's beliefs in his/ her capacity to create effective routes to achieve goals (way power or pathways thinking) and beliefs in his/her ability to initiate and sustain movement towards those goals (willing power or agency). It is 'a positive motivational state that is based on an interactively derived sense of successful agency (goal-directed energy) and pathways (planning to meet goals)' (Snyder, Irving, \& Anderson, 1991, p. 287). Agency thinking is the motivational component in hope theory, and it is particularly crucial in the case of impediments (Snyder, 1994).

Within this perceptive, hope is a critical construct to understand how children deal with others and work towards goals, such as developing a good friendship, in an adaptive, effective manner (see Roberts et al., 2005). Measures of children's hope are positively related with self reported competence and feeling about themselves, and it is predictor of self-esteem (Snyder, McDermott, et al., 1997; Snyder, Feldman, Taylor, Schroeder, \& Adams, 2000). Also, the Lewis and Kliewer's (1996) study, focusing on pediatric population, showed that hope was negatively associated with anxiety, but this association was moderated by coping strategies. A research by Barnum et al. (1998) revealed that high-hope had protective function in children to allow them to be effective in their lives in spite of the obstacles.

Hopeful people, like optimistic people, expect positive outcomes even when they face difficulties, in which they insist in pursuit their goals and regulate themselves, using effective coping strategies, so they enhance the chances to achieve their goals (Carver, \& Scheier, 2005; Scheier, Carver, \& Bridges, 2000; Peterson, 2000; Seligman, 1991). Hopeful people, additionally, focus not only on future goals but also on goals they believe they can achieve (see Nolen-Hoeksema, \& Davis, 2005, Snyder, 2000). That means that hopeful individuals are looking for something positive in a variety of conditions.

Accordantly, a high hope child may use optimistic attribution pattern in explaining positive or negative friendships. Probably, a high- hope child, as an optimistic child does, attribute failure to external, unstable and specific factors instead of internal, stable and global factors (see Scheier, \& Carven, 1985; Snyder et al., 2005; Seligman, 2002).

In Snyder's hope theory, emphasizing the thinking processes, 'goal-pursuit cognitions cause emotions' (Snyder et al. 2005, p. 258). Specifically, positive emotions result from perception of successful goal pursuit which reflects unimpeded movement toward the goal or effective overcoming the obstacles. In contrast, negative emotions are formulated by the perception of unsuccessful goal pursuit which may result from insufficient agency thinking and/or pathway thinking or the ineffective ability to overcome the problem. These points were supported by respective researches (e.g., Snyder et al., 1996; Stephanou, 2010), and are in agreement with findings for reported lessened well-being stern from perceived difficulties in pursuit of important goals (Diener, 1984; Ruehlman, \& Wolchik, 1988).

Summarizing, hope influences thought, feelings, expectations and behavior in close relationships.

\section{Aim and Hypotheses of the Study}

This study aimed to examine 1) children's attributions and emotions for their subjectively perceived positive and negative friendships with their best friend, 2) the role of children's hope (pathways thinking, agency thinking) in the generation of their perceptions of the friendships as positive or negative, in the formulation of the subsequent attributions and emotions, and in the impact of attributions on emotions, and 3) the effects of hope (pathways thinking, agency thinking) in the formulation of expectations of the quality of the friendship in the future, and in the interactive impact of attributions and emotions on the friendship expectations.

The hypotheses of the study were the following: The perceived positive or negative friendships will be attributed to selfrelated and other-related factors, respectively (Hypothesis 1a). Locus of causality will be the most powerful attributional dimension in discriminating the group of children who will perceive their friendship as positive from the group of children who will perceive their friendship as negative (Hypothesis 1b). The children will experience various emotions for their perceived positive or negative friendships (Hypothesis 2a). The 
perceived positive and negative friendships will produce positive and negative emotions, respectively (Hypothesis 2b), particularly outcome-dependent emotions (Hypothesis 2c).

The perceived positive friendship group, compared to perceived negative friendship group, will have higher hope (Hypothesis $3 \mathrm{a}$ ). Hope, mainly agency thinking, will have positive effects on the generation of perceiving the friendship as positive and, mainly, as negative (Hypothesis $3 b$ ).

Hope will have positive effects (particularly in negative friendships) on the formulation of attributional dimensions, mainly, stability (Hypothesis 4a), emotions, mainly expectancyrelated emotions (Hypothesis $4 \mathrm{~b}$ ), and on the impact of attributions on emotions (Hypothesis $4 \mathrm{c}$ ).

Hope will positively influence the generation of expectations of the quality of the friendship in the future (Hypothesis 5a), and the interactive effect of attributions and emotions on friendship expectations (Hypothesis 5b), mainly in the case of negative friendships (Hypothesis 5c).

\section{Method}

\section{Participants}

A total of 322 children, of both genders (girls $=173$, and boys $=149$ ), of Grades 5 and 6 participated in this study. Their age ranged from 10 to 12 years $(\mathrm{M}=11.15$ years, $\mathrm{SD}=.74)$. They came from schools of various towns of Greece, representing various parental socioeconomic levels. Of the participants, 233 and 89 children perceived their friendship as positive and negative, respectively (see measurements below).

\section{Measurements}

The consistency of the scales was based on previous relevant to the topic literature (e.g., Bowker et al., 2006; Fletcher, 2002; Fincham, 2003; Holder, \& Coleman, 2009; Stephanou, 2005, 2007; Stephanou, \& Balkamou, 2010; Snyder et al., 2005; Weiner, 2001, 2006), and on findings from a pilot research.

Perceptions of friendship. Children's perceptions of the quality of their friendships with their best friends were estimated by responding to a five-point four items scale ("How good is this friendship?", "How much satisfied are you with this friendship?"). Responses ranged from $1=$ not at all to $5=$ very much. Children themselves defined their friendships as positive or negative by completing the friendship scale twice. More precisely, they, first, filled it for the current quality of their friendship, and, then, mentioned the lowest value in each item over which the friendship would be positive. Children whom the friendship was lower than the indicated as positive formed the group of negative friendship, while those whose friendship was equal or higher than the indicated one formed the group of positive friendship. Cronbach's alphas were .85 and .82 for the positive and negative friendship, respectively.

Attributions for friendship. Children's attributions for the perceived quality of their friendships were examined via the slightly modified Causal Dimension Scale II (CDSII, McAuley, Duncan, \& Russell, 1992), which is a reliable and valid research instrument in examining attributions for intimate interpersonal relationships in Greek population (see Stephanou, 2005, 2007, 2010). The children indicated the most important factor which, according to their opinion, influenced the quality of their friendship, how much this factor contributed to the given friendship, and classified that cause along the causal dimensions of locus of causality (internal/external causes to him/ herself), stability (stable/unstable causes over time), personal controllability (controllable/uncontrollable causes by their own), external controllability (controllable/uncontrollable causes by others), friend's locus of causality (internal/external causes to their friend), friend's controllability (controllable/uncontrollable causes by their friend), self-friend interactive locus of causality (internal/external causes to interaction self-friend) and self-friend interactive controllability (controllable/uncontrollable causes by interactive self-friend). Each subscale consists of three items, ranging form the negative pole $1=$ not at all stable to the positive pole $7=$ totally stable. Cronbach's alphas were .82 for locus of causality, .85 for stability, .75 for personal controllability, .72 for external controllability, .76 for friend's locus of causality, .72 for friend's controllability, .71 for selffriend locus of causality, and .70 for self-friend controllability.

Emotions for friendship. Children's emotions for their friendships with their best friend were assessed by mentioning the extent to which they experienced twelve emotions: happiness, pleasure, pride, encouragement, love, not angry-angry, cheerfulness, confidence, calmness, not anxiety-anxiety, enthusiasm and excitement. The emotions had the form of adjectives with two opposite poles, with the positive pole having the high score of 7 and the negative one having the low score of 1 (e.g., happy 7654321 unhappy). The consistency of the scale was based on previous research (see Stephanou, 2004, 2007; Weiner, 1992, 2001).

Friendship expectations. Children's friendship expectations were examined via the scale of the perceived current quality of the friendship. The wording of the questions for the two scales was the same except for the verb tense ("How good will this friendship be in the future", "How much satisfied will you be with this friendship in the future?"). Cronbach's alphas were .84 and .80 for the positive and negative friendship, respectively,

Hope. Children's dispositional hope was examined via the Children's Hope Scale for ages 8 to 16 (Snyder, Hoza, et al., 1997) which comprises three agency thinking (e.g., "I think I am doing pretty well") and three pathways thinking (e.g., "I can think of many ways to get the things in life that are most important to me") items. Responses ranged from $1=$ None of the time to $6=$ All of the time. The scale was independently translated from English into Greek by two familiar to the topic researches, and, then, there was a backward translation by a native English speaker. The feedback was positive for the Greek version of the scale. Cronbach's alphas were .89 and .86 for agency thinking and pathways thinking, respectively.

Personal factors. Children's personal information scale consisted of a set of questions relevant to personal factors, such as age, grade and gender.

\section{Procedure}

The children initially completed the hope scale. After one week, all the participants were asked, first, to write down the name of their best friend, and, then, to fill out the scales that refer to this specific friendship. The children individually completed the scales in front of the researcher in quite classrooms in their schools. In order to ensure that any relationship among the examined variables was not due to procedure used, the participants completed first the emotions scale and then the scales of the perceived quality of their friendship and the attributions. To match the questionnaires that were responded by the same child, children were asked to choose a code name and use it on the questionnaires. The children were assured of anonymity and confidentiality. 


\section{Results}

\section{Attributions and Emotions for the Perceived Positive and Negative Friendship}

The results from the repeated measures MANOVAs (using the Wilks's lambda estimate) with the eight attributional dimensions as within-subjects factor and the perceived friendship (positive/negative) as between-subjects factor revealed significant effect of the attributional dimensions, $F(7,314)=53.80, p$ $<.01, \eta^{2}=.54$, significant effect of the perceived friendship $\mathrm{F}(1$, $320)=93.00, \mathrm{p}<.01, \eta^{2}=.22$, and significant multivariate effect, $\mathrm{F}(7,314)=31.80, \mathrm{p}<.01, \eta^{2}=.41$. The results from subsequent repeated measures ANOVAs, examining differences between attributions within each group (positive/negative) of friendship, post hoc pairwise comparisons and the mean scores (Table 1) indicated that the children made internal, personal controllable, external uncontrollable, stable, controllable by their friends, internal to their friends and, mainly, self-friend interactive internal and controllable attributions for the perceived positive friendships. In contrast, they made external, external controllable, personal uncontrollable, and, predominately, stable, friend's controllable and internal, and self-friend interactive internal attributions for the perceived negative friendships.

The results from Discriminant analysis (Table 1), with step- wise method, confirmed the univariate effects and, in addition, showed that personal controllability, discriminating power $=.84, \mathrm{~d}=1.32$, followed by locus of causality, discriminating power $=.60, \mathrm{~d}=1.12$, self-friend interactive controllability, discriminating power $=.59, \mathrm{~d}=1.08$, was the most powerful factor in discriminating the group of children who perceived their friendship as positive from the group of children who perceived their friendship as negative. Furthermore, friend's controllability had no significant contribution in discriminating the two groups of children.

The above results partly confirmed Hypotheses $1 \mathrm{a}$ and $1 \mathrm{~b}$.

The results from the two repeated measures ANOVAs, one for each group of friendship (positive/negative), in which emotions was the within-subjects factor, showed that the participants experienced various emotions and a variety of intensity of emotions for their perceived positive friendships, $F(11,222)=$ $12.52, \mathrm{p}<.01, \eta^{2}=.40$, and negative friendships, $\mathrm{F}(11,78)=$ $4.60, \mathrm{p}<.01, \eta^{2}=.41$. Inspection of the scores (Table 2 ) and the post hoc pairwise comparisons indicated that the children experienced intense positive emotions, mainly enthusiasm, happiness, cheerfulness, pleasure and confidence, for their perceived positive friendships. In contrary, the children felt intense negative emotions, predominately non confidence, not excitement, sadness and anxiety, for their perceived negative friendships. Discriminant analysis, with stepwise method, was con-

Table 1.

Descriptive statistics and results from Discriminant analysis for children's attribution for their perceived positive and negative friendships.

\begin{tabular}{ccccccccc}
\hline & \multicolumn{1}{c}{ Positive friendship } & \multicolumn{2}{l}{ Negative friendship } & & \\
\hline Attributional dimensions & Mean & SD & Mean & SD & Wilks' Lambda & Discriminating power & d & F \\
Locus of causality & 5.78 & 1.09 & 4.42 & .74 & .74 & .60 & 1.12 & 108.26 \\
Personal controllability & 5.62 & 1.08 & 3.86 & 1.03 & .64 & .79 & 1.32 & 173.62 \\
Stability & 5.66 & 1.21 & 5.07 & .80 & .94 & .25 & .51 & 18.13 \\
External controllability & 3.18 & 1.63 & 4.47 & .91 & .86 & .42 & .81 & 49.54 \\
Friend's locus of causality & 5.73 & 1.16 & 4.96 & .70 & .89 & .37 & .73 & 38.91 \\
Friend 's personal controllability & 5.44 & 1.15 & 5.01 & .53 & .96 &.- & .41 & 11.23 \\
Self-friend interactive locus causality & 5.92 & 1.02 & 4.99 & 1.03 & .85 & .44 & .80 & 53.61 \\
Self-friend interactive controllability & 6.01 & 1.04 & 4.84 & .63 & .76 & .59 & 1.08 & 98.36 \\
\hline
\end{tabular}

Note: All $\mathrm{F}(1,320)$ values $\mathrm{p}<.01$; --: Attributional dimensions did not to further differentiate the one group from the other group of children.

Table 2.

Descriptive statistics and findings from Discriminant analysis for children's emotions for their perceived positive and negative friendships.

\begin{tabular}{|c|c|c|c|c|c|c|c|c|}
\hline \multirow[b]{2}{*}{ Emotions } & \multicolumn{2}{|c|}{ Positive friendship } & \multicolumn{2}{|c|}{ Negative friendship } & \multirow[b]{2}{*}{ Wilks' Lambda } & \multirow[b]{2}{*}{ Discriminting power } & \multirow[b]{2}{*}{ Cohen's d } & \multirow[b]{2}{*}{$\mathrm{F}$} \\
\hline & Mean & SD & Mean & SD & & & & \\
\hline Happiness & 4.48 & .65 & 1.89 & 1.44 & .39 & -- & 1.73 & 493.05 \\
\hline Pleasure & 4.50 & .63 & 2.17 & 1.35 & .42 & .76 & 1.70 & 440.58 \\
\hline Pride & 4.14 & .84 & 2.30 & 1.44 & .61 & .53 & 1.39 & 199.46 \\
\hline Love & 4.28 & .76 & 2.01 & 1.38 & .47 & -- & 1.61 & 348.78 \\
\hline Encouragement & 4.36 & .70 & 2.25 & 1.37 & .49 & .68 & 1.58 & 328.38 \\
\hline No anger-angry & 4.21 & .96 & 2.00 & 1.38 & .55 & -- & 1.92 & 262.33 \\
\hline Cheerfulness & 4.55 & .71 & 1.80 & 1.48 & .39 & .84 & 1.75 & 500.03 \\
\hline Excitement & 4.09 & .84 & 1.70 & 1.40 & .47 & -- & 1.61 & 351.86 \\
\hline Confidence & 4.40 & .71 & 1.74 & 1.42 & .39 & .83 & 1.75 & 488.14 \\
\hline Calmness & 4.04 & 1.01 & 1.88 & 1.39 & .57 & -- & 1.15 & 236.38 \\
\hline Non anxiety-anxiety & 4.08 & .95 & 1.84 & 1.41 & .54 & -- & 1.80 & 268.13 \\
\hline Enthusiasm & 4.57 & .76 & 1.89 & 1.44 & .40 & .81 & 1.73 & 463.70 \\
\hline
\end{tabular}

Note: All $\mathrm{F}(1,320)$ values are significant at the .01 level of significance; The nature of the emotions is positive and negative in the positive and negative friendships group, respectively; --: Emotions did not further differentiate the one group from the other group of children. 
ducted to determine the set of emotions that best discriminated the two groups of children. The results from this analysis (Table 2) confirmed the univariate findings, and, in addition, revealed that: 1) the children, who estimated their friendship as positive, compared to children, who estimated their friendship as negative, felt better, 2) the emotion of cheerfulness, discriminating power $=.84, \mathrm{~d}=1.75$, followed by the emotions of confidence, discriminating power $=.83, \mathrm{~d}=1.75$, enthusiasm, discriminating power $=.81, \mathrm{~d}=1.73$, and pleasure, discriminating power $=.76, \mathrm{~d}=1.70$, was the most powerful factor in discriminating the group of students with the positive friendships from the group of students with the negative friendships and 3) the emotions of happiness, love, no angry-angry, excitement, calmness, no anxiety-anxiety were found not to further differentiate the one group from the other group of children.

The above results partly confirmed Hypotheses $2 \mathrm{a}, 2 \mathrm{~b}$ and 2c.

\section{The role of Hope in the Perceived Positive and Negative Friendships}

The results from Anovas, with the perceived (positive/negative) friendship as between subjects factor, and examination of the mean scores revealed that the children who estimated their friendships as positive, as compared to children, who perceived their friendships as negative, had higher agency thinking and higher pathway thinking. The results from Discriminant analysis (Table 3) with stepwise method confirmed these findings and, in addition, showed that agency thinking, discriminating power $=.95, \mathrm{~d}=1.42$, discriminated the one from the other group of children, while path thinking did not to further differ- entiate the two groups of children.

Because we were also interested in the role of hope within positive/negative friendship, correlations coefficients and regression analyses within each group of friendships were conducted. The results from these analyses showed that the higher levels of hope (mainly, agency thinking) were associated with higher perceived positive friendships and with lower perceived negative friendships. More precisely, in the positive friendships group, agency thoughts and pathways thoughts, together, influenced the students' perceptions of their friendships, $\mathrm{R}^{2}=.12$, $\mathrm{F}(2,230)=19.35, \mathrm{p}<.01$, agency thoughts, $\mathrm{b}=.35, \mathrm{t}=4.25, \mathrm{p}$ $<.01$, had unique effect on it, while pathways thoughts had not significant effect, $\mathrm{b}=.02, \mathrm{t}=1.00, \mathrm{p}>.05$. In the negative friendships group, pathways thoughts and agency thoughts, as a group, influenced the generation of the perceived friendships, $\mathrm{R}^{2}=.69, \mathrm{~F}(2,86)=97.45, \mathrm{p}<.01$, agency thoughts, $\mathrm{b}=.70, \mathrm{t}=$ $3.55, \mathrm{p}<.01$, contributed into it, while pathway thinking was not significant contributor, $\mathrm{b}=.13, \mathrm{t}=.67, \mathrm{p}>.05$.

Thus, Hypotheses $3 \mathrm{a}$ and $3 \mathrm{~b}$ were partly confirmed.

\section{Effects of Hope on Attributions for the Perceived Positive and Negative Friendships}

Correlations coefficients, and a series of regression analysis (Table 4), with agency thinking and pathway thinking as predictive variables and each of the attributional dimensions as predicted variable, within each group (positive/negative friendship) of children revealed the following.

Agency thoughts and pathways thoughts, together, positively influenced the formulation of the attributional dimensions, explaining an amount of variance from $3 \%$ (external controllability) to $18 \%$ (stability) in the positive friendships group, and

Table 3.

Descriptive statistics and results from Discriminant analysis for the effects of children's hope on their perceived friendships (positive/negative).

\begin{tabular}{|c|c|c|c|c|c|c|c|c|}
\hline \multirow[b]{2}{*}{ Hope } & \multicolumn{2}{|c|}{ Positive friendship } & \multicolumn{2}{|c|}{ Negative friendship } & \multirow[b]{2}{*}{ Wilks' Lambda } & \multirow[b]{2}{*}{ Discriminating power } & \multirow[b]{2}{*}{ Cohen's d } & \multirow[b]{2}{*}{$\mathrm{F}^{*}$} \\
\hline & Mean & SD & Mean & SD & & & & \\
\hline Agency thinking & 14.32 & 3.00 & 8.04 & 4.30 & .59 & .95 & 1.42 & 218.23 \\
\hline Pathway thinking & 14.19 & 2.86 & 8.75 & 4.30 & .65 & -- & 1.32 & 172.64 \\
\hline
\end{tabular}

Note: All F(1,320) values, $\mathrm{p}<.01 ;$--: Pathway thinking did not further differentiate the one group from the other group of children.

Table 4 .

Findings from regression analyses for the effects of children's hope (agency thinking, path thinking) on attributional dimensions for their perceived positive and negative friendships.

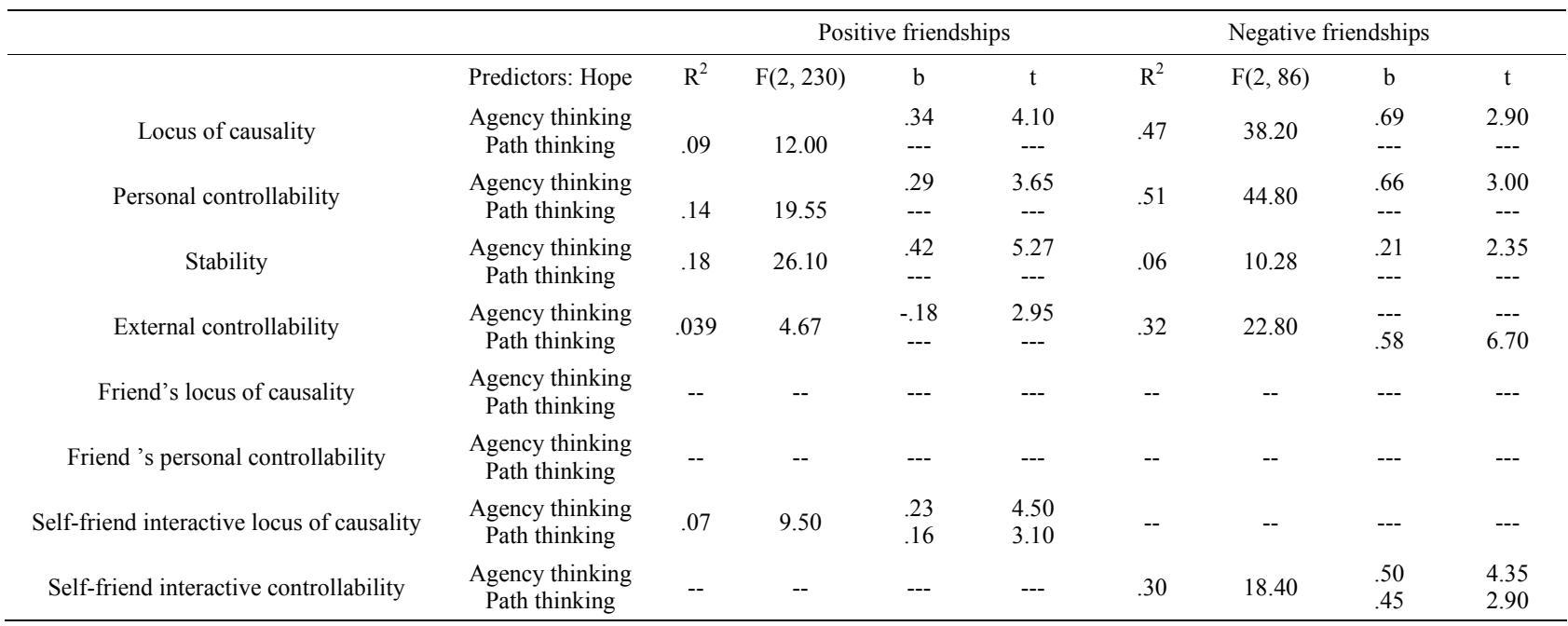

Note: $\mathrm{F}>4.67, \mathrm{p}<.01 ; \mathrm{F} \leq=4.67, \mathrm{p}<.05 ; \mathrm{F}--, \mathrm{p}>.05 ; \mathrm{t}---, \mathrm{p}>.05, \mathrm{t} \geq 2.35, \mathrm{p}<.01$. 
from $30 \%$ (self-friend interactive controllability) to $51 \%$ (personal controllability) in the negative friendships group. Thus, hope was a better predictor of the attributional dimensions for the perceived negative friendships than for the perceived positive friendships. Higher-hope children, as compared to lowerhope children, made more internal, personal controllable, stable, external uncontrollable and self-friend interactive internal attributions for their perceived positive friendships, and more external, personal uncontrollable, external controllable, and self-friend interactive uncontrollable attributions their perceived negative friendships.

Pathways thoughts accounted for significant variability only in self-friend interactive locus of causality and self-friend interactive controllability in the positive and negative friendships group, respectively. In contrast, agency thoughts evidenced unique contribution in the generation of all of the attributional dimensions.

Thus, Hypotheses 4a was mainly confirmed.

\section{Effects of Hope on Emotions for the Perceived Positive and Negative Friendships}

The results from correlations coefficients and a series of regression analyses, with agency thinking and pathway thinking as predictive variables and each of the emotions as predicted variable, within each group (perceived positive/negative friendships) (Table 5) showed that 1) agency thoughts and pathways thoughts, as a group, was a significant formulator of the children's emotions for their positive friendships, $\mathrm{R}^{2}$ ranged from .03 (pride) to .11 (confidence), and, mainly, of their emotions for their negative friendships, $\mathrm{R}^{2}$ ranged from .30 (calmness) to .80 (encouragement), 2) higher-hope children, in comparison to lower-hope children, experienced more intense positive emotions (mainly, encouragement and confidence) for their positive friendships, while they felt less negative emotions (particularly, discouragement, hate, and shame) for their negative friendships, 3) the relative power of pathway thinking and agency thinking in formulating emotional experience varied across emotions and between the two groups of friendships, and 4) pathway thinking, compared to agency thinking, was a better predictor of most of the emotions in the positive friendships group, while in the negative friendships group the reverse was the case.

The above findings partly confirmed the hypothesis $4 \mathrm{~b}$.

\section{Effects of Hope on the Impact of Attributions on Emotions for the Perceived Friendship}

Because we were also interested in the mediate role of hope in the impact of the attributions on the emotions for the perceived positive and negative friendship, a series of hierarchical regression analysis were conducted. Each of the emotions was the predicted variable, and attributional dimensions were entered at the first step, and agency thoughts and pathway thoughts were entered at the second step of the analysis ${ }^{1}$.

The results from the analyses (Table 6) revealed that 1) hope and attributions, in combination, accounted for a significant variance in the emotions for the perceived positive friendships, $\mathrm{R}^{2}$ ranged from .08 (encouragement) to .18 (happiness), and, mainly, for perceived negative friendships, $\mathrm{R}^{2}$ ranged from .57 (nervousness) to .88 (displeasure), 2) hope (agency thinking and pathways thinking, together) enhanced the impact of the attributions on the emotions for the perceived positive friend-

${ }^{1}$ Only the variables that were significantly related to each-other were included in the analysis. ships, $\mathrm{R}^{2}$ ch ranged from .032 to .057 , and, mostly, for the perceived negative friendships, $\mathrm{R}^{2} \mathrm{ch}$ ranged from .034 to. 65 . That means that the children with higher hope (mainly, agency thinking) were more likely to use the specific attributional pattern and enjoy their friendships more than the children with lower hope. Also, 3) agency thinking had unique effect on most of the emotions, whereas pathway thinking had unique effect on confidence and encouragement. Finally, 4) locus of causality, personal controllability, and self-friend interactive controllability, compared to the other attributional dimensions, were better predictors of most of the emotions.

The above findings partly confirmed Hypotheses 4c.

\section{Effects of Hope on the Interactive Impact of Attributions and Emotions on Friendship Expectations}

In order to examine the role of hope on the effects of the attributions and emotions for the perceived quality of the friendship on the friendship expectations, correlation coefficients and two hierarchical regression analyses were performed. The findings revealed that, in the positive friendships group, highpathway thinking children expected that their friendship will continue to be good in the future. In contrast, in the negative friendships group, low-agency thinking children had low expectations of positive friendship. In addition, the main results from the two hierarchical regression analyses (Table 7), with friendship expectations as predicted factor, and emotions entering into first step, attributions entering into second step and hope entering into third step of the analysis, were the following: a) the three sets of predictors, together, had significant and positive effect on friendship expectations in the positive friendships group, $\mathrm{R}^{2}=.47$, and in the negative friendship group, $\mathrm{R}^{2}$ $=.96, \mathrm{~b})$ pathways thoughts and agency thoughts, together, influenced the interactive impact of attributions and emotions on friendship expectations in both groups of friendships, positive, $\mathrm{R}^{2} \mathrm{ch}=.029$, and negative, $\mathrm{R}^{2} \mathrm{ch}=.052$, c) pathways thoughts and agency thoughts enhanced the impact of attributions and emotions on friendship expectations in the positive friendships group and negative friendships group, respectively, d) pleasure, encouragement, cheerfulness, confidence, calmness, stability, external controllability, self-friend interactive locus of causality, and pathway thoughts uniquely contributed into friendship expectations in the positive friendships group, and e) displeasure, discouragement, hate, sadness, no excitement, no enthusiasm, personal controllability, external controllability, self-friend interactive controllability and agency thoughts were significant predictors of friendship expectations in the negative friendships group. Hypotheses $5 \mathrm{a}, 5 \mathrm{~b}$ and $5 \mathrm{c}$ were in the main confirmed by these findings.

\section{Discussion}

The main aim of this study was to investigate a) possible differences between the children who perceive their friendship with their best friend either as positive or negative with respect to subsequent attributions and emotions, and hope (pathways thinking, agency thinking, and b) the role of hope in the generation of attributions, emotions and friendship expectations.

The attributional pattern for the friendships was in the main as expected. The children attributed their friendships with their best friends to various causes, reflecting the high importance of such relationships in their life (Argyle, 2001; Berndt, 2004; Bukowski, 2001; Holder \& Coleman, 2009; Stephanou, 2010; 
Table 5 .

Findings from regression analyses for the effects of children's hope (agency thinking, path thinking) on their emotions for their perceived positive and negative friendships.

\begin{tabular}{|c|c|c|c|c|c|c|c|c|c|}
\hline & \multicolumn{6}{|c|}{ Positive friendships } & \multicolumn{3}{|c|}{ Negative friendships } \\
\hline & Predictors: Hope & $\mathrm{R}^{2}$ & $\mathrm{~F}(2,230)$ & $\mathrm{b}$ & $\mathrm{t}$ & $\mathrm{R}^{2}$ & $F(2,86)$ & $\mathrm{b}$ & $\mathrm{t}$ \\
\hline Happiness & $\begin{array}{l}\text { Agency thinking } \\
\text { Path thinking }\end{array}$ & .06 & 7.90 & $\begin{array}{l}.18 \\
---\end{array}$ & $\begin{array}{c}2.12 \\
---\end{array}$ & .51 & 46.45 & $\begin{array}{l}.95 \\
---\end{array}$ & $\begin{array}{c}3.88 \\
---\end{array}$ \\
\hline Pleasure & $\begin{array}{l}\text { Agency thinking } \\
\text { Path thinking }\end{array}$ & -- & -- & -- & --- & .71 & 106.94 & $\begin{array}{l}.97 \\
---\end{array}$ & $\begin{array}{c}5.10 \\
---\end{array}$ \\
\hline Pride & $\begin{array}{l}\text { Agency thinking } \\
\text { Path thinking }\end{array}$ & .03 & 4.00 & $\begin{array}{l}.18 \\
---\end{array}$ & $\begin{array}{c}2.80 \\
---\end{array}$ & .75 & 135.20 & $\begin{array}{l}.96 \\
---\end{array}$ & $\begin{array}{c}5.70 \\
---\end{array}$ \\
\hline Love & $\begin{array}{l}\text { Agency thinking } \\
\text { Path thinking }\end{array}$ & -- & -- & --- & --- & .77 & 145.10 & $\begin{array}{l}.98 \\
---\end{array}$ & $\begin{array}{c}6.30 \\
---\end{array}$ \\
\hline Encouragement & $\begin{array}{l}\text { Agency thinking } \\
\text { Path thinking }\end{array}$ & .07 & 9.23 & --- & 3.52 & .80 & 172.50 & $\begin{array}{l}.77 \\
---\end{array}$ & 4.84 \\
\hline Not angry-angry & $\begin{array}{l}\text { Agency thinking } \\
\text { Path thinking }\end{array}$ & .04 & 7.00 & .21 & 3.27 & .71 & 109.45 & $\begin{array}{l}.70 \\
---\end{array}$ & $\begin{array}{c}3.70 \\
---\end{array}$ \\
\hline Excitement & $\begin{array}{l}\text { Agency thinking } \\
\text { Path thinking }\end{array}$ & .09 & 11.30 & $\begin{array}{l}.38 \\
.17\end{array}$ & $\begin{array}{l}4.60 \\
2.80\end{array}$ & .58 & 60.10 & $\begin{array}{l}.90 \\
---\end{array}$ & $\begin{array}{c}4.20 \\
---\end{array}$ \\
\hline Confidence & $\begin{array}{l}\text { Agency thinking } \\
\text { Path thinking }\end{array}$ & .11 & 15.60 & $\begin{array}{l}.17 \\
.20\end{array}$ & $\begin{array}{l}2.25 \\
2.43\end{array}$ & .57 & 58.35 & $\begin{array}{l}.90 \\
---\end{array}$ & $\begin{array}{c}3.95 \\
---\end{array}$ \\
\hline Calmness & $\begin{array}{l}\text { Agency thinking } \\
\text { Path thinking }\end{array}$ & -- & -- & -- & --- & .30 & 18.60 & $\begin{array}{l}.68 \\
.43\end{array}$ & $\begin{array}{l}3.40 \\
2.65\end{array}$ \\
\hline No anxiety-anxiety & $\begin{array}{l}\text { Agency thinking } \\
\text { Path thinking }\end{array}$ & -- & -- & --- & -- & .49 & 44.65 & $\begin{array}{l}.77 \\
.52\end{array}$ & $\begin{array}{l}4.65 \\
2.30\end{array}$ \\
\hline Enthusiasm & $\begin{array}{l}\text { Agency thinking } \\
\text { Path thinking }\end{array}$ & .05 & 6.30 &.-- & $\begin{array}{c}--- \\
2.67\end{array}$ & .54 & 50.90 & $\begin{array}{l}.80 \\
.41\end{array}$ & $\begin{array}{l}4.70 \\
2.25\end{array}$ \\
\hline
\end{tabular}

Note: $\mathrm{F}>4.00, \mathrm{p}<.01 ; \mathrm{F} \leq=4.00, \mathrm{p}<.05 ; \mathrm{F}--, \mathrm{p}>.05 ; \mathrm{t}>2.80, \mathrm{p}<.01 ; \mathrm{t} \leq 2.80, \mathrm{p}<.05 ; \mathrm{t}---, \mathrm{p}>.05$; The nature of the emotions is positive and negative in the positive and negative friendships group, respectively.

Stephanou, \& Balkamou, 2010). In addition, the attributional pattern within- and between positive and negative friendships group appears to be related to desirable good friendship (see Gifford-Smith \& Brownell, 2003; Harvey et al., 2005; Hoglund et al., 2008; Weiner, 2002, 2005). Also, by attributing the positive friendships to personal properties, along with friend related factors, self-friend interactive internal and controllable causes, the participants enhanced themselves, multiplied the chances of good relationship in the future, and, simultaneously, indicated the crucial role of the friend in forming a satisfactory friendship (Fiedler et al., 1995; Fincham, 2003; Rusbult, Arriaga, \& Agnew, 2003; Weiner, 2001). By attributing the negative friendships to external, personal uncontrollable and friend's internal and controllable bad factors, the children protected themselves (see Stephanou, 2005, 2007; Weiner, 2001). However, considering the friend as responsible for the negative friendship does not facilitate future positive relationship (Karney et al., 2003; Mason, 2001; Weiner, 1995). Similarly, attributing the non satisfactory friendship to constant and external controllable negative factors minimizes the chances for future positive friendship (Fletcher, 2002; Fincham et al., 1998; Planalp, \& Rivers, 1996).

The findings regarding the emotions were mainly in consistency with our hypotheses and previous research evidence. Perhaps, it was very important for the children to have positive friendships, since they reacted affectively in high intense (Forgas, 2002; Forgas, \& Smith, 2005; Frijda, 1993, 2009). Also, the children, being at the specific age, might have expected positive friendships, and confirmation of them produced intense positive emotions (see Bless, 2003; Trope, \& Gaunt,
2005), while, the friends' unexpected bad behavior contributed into intense negative emotions. This argument is related to the Berscheid (1983) emotion-in-relationships model suggesting the greater the interruption when one partner does something unexpected, or fails to do something expected, the higher the intensity of the experienced emotions. Additionally, it seems that the children' negative friendships with their best friends were against their desires, since under such conditions persons experience intense negative emotions (Berscheid, \& Ammazalorso, 2003; Carver, \& Scheier, 2000; Forgas, 2002; Frijda, 2007, 2009; Parrott, 2003). The fact that the group of children with the positive friendships was discriminated from the group of children with the negative friendships predominately by the outcome-dependent affects (cheerfulness, pleasure), followed by the expectancy-related affects (confidence, enthusiasm, encouragement), and self-esteem related affects (pride) is also in line with these speculations and Weiner's $(2002,2005)$ theory.

Children also experienced discrete emotions by cognitively appraised their friendships along the attributional dimensions. This finding is in agreement with other researches (e.g., Bradbury, \& Fincham, 1987; Fitness \& Fletcher, 1993; Planalp \& Fitness, 1999; Stephanou, \& Balkamou, 2010) in intimate relationships. The fact that attributions were more powerful contributor in the generation of the emotions in negative than positive friendships is consistent with the notion that individuals search for explanations of their negative than positive experiences (Weiner, 2002). Locus of causality and personal controllability were found to be the most significant predictors of most of the emotions, contrarily to the notion that each 
Table 6.

Results from hierarchical regression analyses for the impact of hope (agency thinking, path thinking) on the effects of attributions on emotions for the perceived friendships (positive/negative).

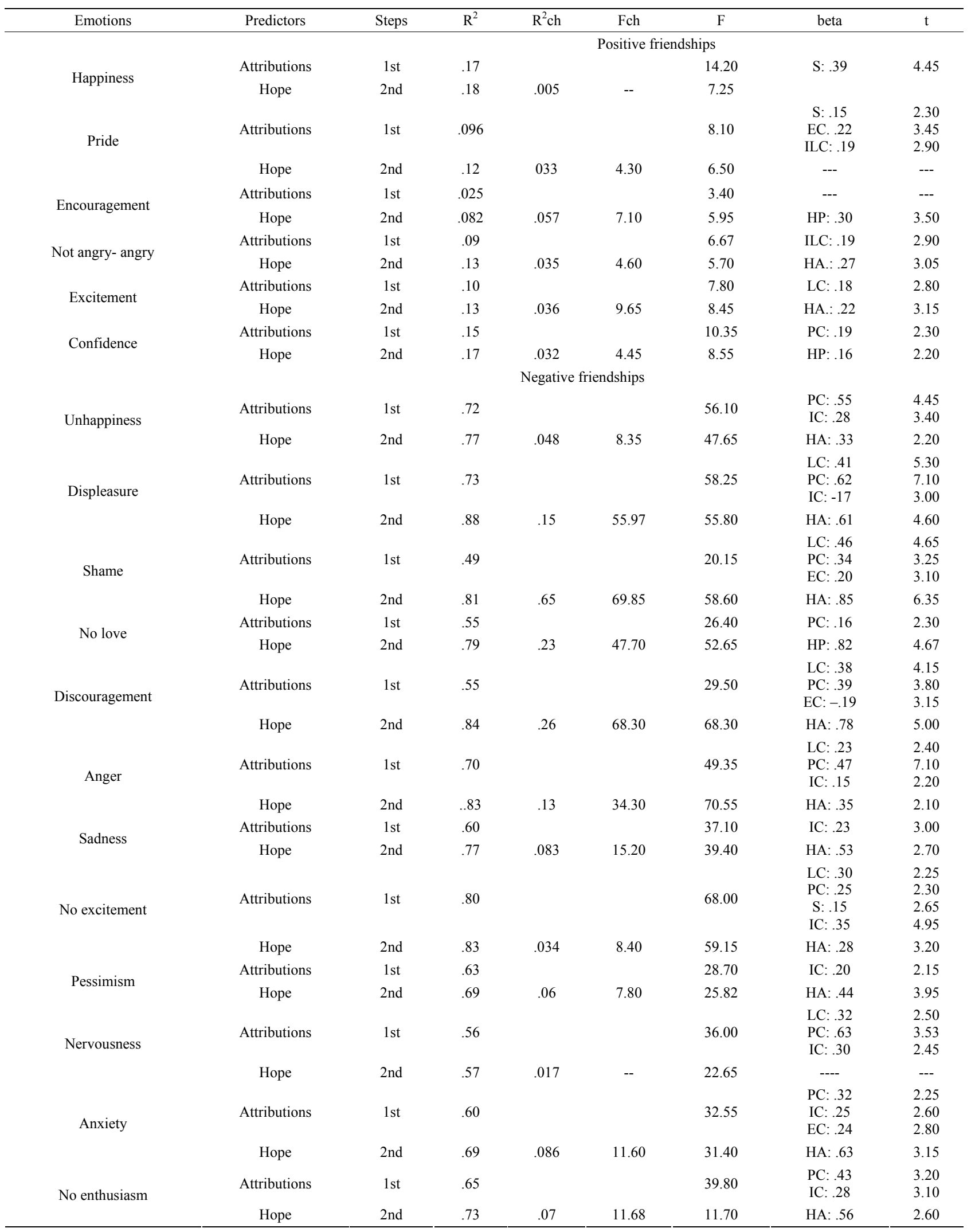

Notes: $\mathrm{LC}=$ Locus of causality; $\mathrm{PC}=$ Personal controllability; $\mathrm{S}=$ Stability; EC = External controllability; ILC = Self-friend interactive locus of causality; IC = Self-friend interactive controllability; Fch- and F-values, $\mathrm{p}<.01 ;--$ : No significant at the .05 level; $\mathrm{t}>2.60, \mathrm{p}<.01 ; \mathrm{t} \leq 2.60, \mathrm{p}<.05 ; \mathrm{t}---: \mathrm{p}>.05$. 
Table 7 .

Findings from regression analyses for the effects of hope on the impact of attributional dimensions on emotions, and in turn on friendship expectations in the perceived positive and negative friendships groups.

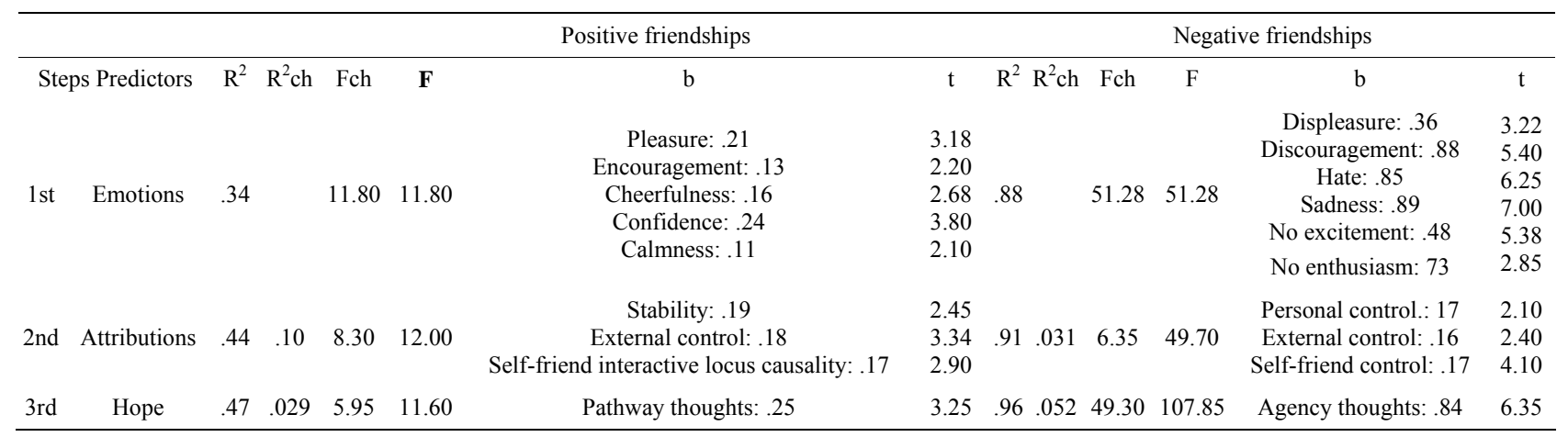

Note: All F- and Fch-values are significant at the .01 level of significance; $\mathrm{t}-\mathrm{p}>.05 ; \mathrm{t}>2.45, \mathrm{p}<.01 ; \mathrm{t} \leq 2.45, \mathrm{p}<.05$.

attributional dimension is related to specific kind of emotions. Self-friend interactive controllability played a significant role in emotions, particularly for negative relationships, underling the interactive nature of friendship (Carr, 2005; Rose, 2007).

Interestingly, it also seems that the children considered the development of their friendship, since, based on Seligman's (2002) view of classification of emotions, they experienced emotions which are related to the past (e.g., pride/shame), the present (e.g., pleasure/displeasure) and the future (e.g., confidence/non confidence).

It should be mentioned, however, that the experience of some certain negative emotions does not facilitate future good friendship. For example, previous research evidence suggests that anger is positively related to attribute malicious intentions to other, anxiety enhances the belief that threating events are about to occur, and sadness shapes malicious attributions for conflicts in close relationships (Fitness et al., 2005; Forgas, 1994, 1995; Planalp, \& Fitness, 1999).

To summarize, the findings regarding hope were mainly consistent with our expectations. More precisely, in accordance to previous studies (see Roberts, 2005; Snyder et al., 2005), and Snyder's (2000) hope theory, the children with high hope enjoyed their friendship with their best friend, and used positive appraisal for their good friendship. In a similar way, the high hope children, as compared to low hope children, suffered less and used effective appraisal of the no satisfactory friendships. These findings indicate that the high hope children, not the low hope children, searched for something positive, a consistent finding with previous empirical evidence (see Carver, \& Scheier, 2005). Hope was also a more powerful contributor into the generation of emotions and of the appraisals of the negative friendship than the positive friendship, complementarily to previous research evidence, which suggests that high hope people use positive reappraisal for a variety of stressor situation (see Gilham, 2000; Snyder et al., 1999).

The differential contribution of pathway thinking and agency thinking to emotional experience and cognitive appraisals of the friendships is an indication that hope is interactively constructed by these two elements (see Snyder et al, 2005). Contrarily to our hypothesis and previous literature, pathway thinking played a minor role in emotions, evaluating and attributing causes of the friendships. This may reflect the notion that agency thinking shares similarity with self-efficacy (Bandura, 1997), and, being the motivational component of hope, proved crucial in the case of difficulties, like negative friendship (see Snyder, 1994).
With reference to attributions, in addition, hope predominately influenced stability than the other attributional dimensions for the positive friendship, while, unexpectedly, it mainly influenced locus of causality and personal controllability for the negative friendship, reflecting, probably, the children's desire and assurance only for the former friendship. These findings may also support other findings which reported that high-hope as compared with low-hope individuals tend to present themselves more positively and social desirable (Snyder, Hoza, et al., 1997; Taylor, 1989). However, research needs to examine this speculation.

The pattern of the effects of hope on emotions is consistent with empirical evidence (see Roberts et al., 2005; Seligman, 2005; Stephanou, 2010) showing the important role of hope in expectancy (encouragement/discouragement, confidence/non confidence, enthusiasm/non enthusiasm)-, goal pursuit (pleasure/displeasure, cheerfulness/sadness, love/hate)-, self (pride/ shame)-related affects. Furthermore, hope had direct and indirect, through attributions, effect on the emotions for the perceived positive friendships and, mainly, negative friendships.

The results from the present study also, confirming in the main our hypotheses, reveal that hope, attributions and emotions had unique and complimentarily effect on friendship expectations. Specifically, the three sets of concepts, in combination, proved a more powerful predictor of the expectations in negative than positive friendship group, lending further support to the earlier findings (see Fitness et al., 2005; Forgas, \& Smith, 2005; Greitemeyer, \& Weiner, 2003; Harvey et al., 2005; Stephanou, 2007; Weiner, 2002, 2005). Also, in agreement with Weiner's (2002) model the future (encouragement, confidence/ discouragement, no enthusiasm)- and desirable friendship (pleasure, cheerfulness, calmness/displeasure, hate, sadness, no excitement)-related emotions contributed in friendship expectations. Stability, as expected, was a significant factor of the formation of friendship expectation in the positive friendship group, while, unexpectedly, it had no effect in negative friendship group, reflecting, probably, children's beliefs that the negative friendship can become positive only if they can control situation and interact effectively with their friends. The effect of external controllability and self-friend interactive locus of causality is another indication of the perception of the significant role of the friend in forming a future positive friendship. However, these need to be further investigated.

Also, in line with Snyder's (2000) theory and previous research evidence (e.g., Peterson, 2000; Scheier et al., 2000; Stephanou, 2010), hope had direct and indirect (via the interac- 
tion of attributions and emotions) effect on friendship expectations in both groups of children. That means that the children with higher pathway thinking were more likely to use the specific attributional pattern, enjoy their friendships more and have higher expectations of positive friendship than the children with lower pathway thinking. In contrast, in the negative friendship group, the higher agency thinking compared with lower agency thinking, were more likely to apply the specific attributional pattern, suffer in the friendship less, and expect future positive friendship. Interestingly, pathway thinking and agency thinking proved predictor of friendship expectation in the positive and negative friendships, respectively. Research needs to verify their relative role in children's friendship-related procedures.

\section{Implications of the Findings in Children and Research}

Good friendship proved important for the children. Children should be helped develop the capacity to make and maintain stable and satisfying friendships. This capacity is acquired through personal, historical and environmental factors (Blas, 2007; Buss, 2000; Carr, 2005). Regarding environmental factors, children should be encouraged by school, the family and the community to meet peers, at least some of whom have similar skills, attributes and values. With respect to personal factors, in the present study, hope appears to play a significant role in it. More precisely, children had certain hope level that influenced their perceptions of friendship as positive or negative, the subsequent attributions and emotions, and their friendship expectations, particularly in negative friendships group. Hence, children are needed to be helped maximize hopeful thinking, which is inculcated through interactions with their caretakers, teachers and peers (McDermott \& Hastings, 2000; Snyder et al., 1997). Children should be encouraged to formulate clear goals, produce many and various pathways to these, pursue the goals and reframe obstacles as challenge to be overcome (Snyder, 2000).

The present findings also support that the participants were involved in their friendships cognitively and emotionally, and these processes had significant effect on friendship expectations. Attributional retraining (Seligman, 2002) helps children to change maladaptive attributional pattern of friendships, and understanding the nature and function of emotions within positive/negative friendship is essential. Yet, emotional expression influences partners' behaviour (Clark, Pataki, \& Carver, 1996), and children are needed to be aware of it.

Overall, the findings from this study indicate the importance of examining children friendship along the role of hope in evaluating, attributing causes, experiencing emotions and forming expectations. Research is needed to examine the role of children's past experience, beliefs and expectancies about the ideal friendship on the observed associations, and on the consequences of the present emotional and cognitive pattern on friendship development. Finally, research needs to investigate the role of parents' and teachers' support in children's hope thinking and intimate relationships.

\section{References}

Argyle, M. (2001). Social relationships. In M. Hewstone, W. Stroebe, J. P. Codol and G. M. Stepheson (Eds.), Introduction to social psychology. Oxford: Blackwell.

Aspinwall, L. G. \& Staudinger, U. M. (2003). A psychology of human strengths: Some central issues of an emerging field. In L. G. Aspinwall and U. M. Staudinger (Eds.), A psychology of human strengths: fundamental questions and future directions for a positive psychol- ogy (pp. 9-22). San Francisco, CA: Berrett-Koehler Publishers Inc. doi:10.1037/10566-001

Bandura, A. (1997). Self-efficacy. New York: Freeman.

Barnum, D. D., Snyder, C. R., Rapof, M. A., Mani, M. M., \& Thompson, R. (1998). Hope and social support in the psychological adjustment of pediatric born survivors and matched controls. Children's Health Care, 27, 15-30. doi:10.1207/s15326888chc2701_2

Baucom, D. H., Epstein, N. B., \& Stanton, S. (2006). The treatment of relationship distress: Theoritical perspectives and empirical findings. In A. L. Vangelistic, \& D. Perlman (Eds.), The Cambridge handbook of personal relationships (pp. 750-773). NY: Cambridge University Press.

Berndsen, M., \& Manstead, A. S. R. (2007). On the relationship between responsibility and guilt: Antecedent appraisal or elaborated appraisal? European Journal of Social Psychology, 37, 774-792. doi:10.1002/ejsp.397

Berscheid, E. (1983). Emotion. In H. H. Kelley, E. Berscheid, A. Christensen, J. H. Harvey, T. L. Huston, G. Levinger, E. Mclintock, I. A. Reptan and D. R. Peterson (Eds.), Close relationships (pp. 110168). New York: Freemen.

Berscheid, E, \& Ammazzalorso, H. (2003). Emotional experience in close relationships. In G. J. O. Fletcher \& M. S. Clark (Eds.), Handbook of social psychology: Interpersonal processes (pp. 308-330). Oxford: Blackwell.

Blascovich, J., \& Mandes, W. B. (2000). Challenge and threat appraisals: The role of affective cues. In J. P. Forgas (Ed.), Feeling and thinking: The role of affect in social cognition (pp. 131-152). New York: Cambridge University Press.

Bless, H. (2003). The consequences of mood on the processing of social information. In A. Tesser and N. Schwarz (Eds.), handbook of social psychology: Intraindividual processes (pp. 391-412). Oxford: Blackwell.

Bowker, J. C., Rubin, K. H., Burgess, K. B., Booth-LaForce, C., \& Rose-Krasnor, L. (2006). Behavioral characteristics associated with stable and fluid best friendship patterns in middle childhood. MerrilPalmer Quarterly, 52, 671-693.

Bradbury, T. N., \& Fincham, F. D. (1987). Affect and cognition in close relationships: Towards an integrative model. Cognition and Emotion, 1, 59-87. doi:10.1080/02699938708408364

Berndt, T. J. (2004). Children's friendships: Shifts over a half century in perspectives on their development and effects. Merrill Palmer Quarterly, 50, 206-223. doi:10.1353/mpq.2004.0014

Bigelow, B. J. (1997). Children's friendship expectations: A cognitive developmental study. Child Development, 48, 246-253. doi: $10.2307 / 1128905$

Blas, L. D. (2007). A circumplex model of interpersonal attributes in middle childhood. Journal of Personality, 75, 863-897. doi:10.1111/j.1467-6494.2007.00459.x

Bukowski, W. (2001). Friendship and the worlds of childhood. In D. W. Nagle and C. A. Erdley (Eds.), The role of friendship in psychological adjustment: New directions for child and adolescent development (pp. 93-106). San Francisco: Jossey-Bass.

Buss, D. (2000). The evolution of happiness. American Psychologist, 55, 15-23. doi:10.1037/0003-066X.55.1.15

Buss, D. 2005. The handbook of evolutionary psychology. NJ: Wiley.

Carr, A. (2005). Positive psychology. London: Routledge.

Carver, C. S., \& Scheier, M. F. (2000). Scaling back goals and readibration of the affect system are processes in normal adaptive selfregulation: Understanding 'response shift' phenomena. Social Science and Medicine, 50, 1715-1722. doi: 10.1016/S0277-9536(99)00412-8

Carver, C. S., \& Scheier, M. F. (2005). Optimism. In C. R. Snyder and S. J. Lopez (Eds.), Handbook of positive psychology (pp. 231-256). Oxford: University Press.

Clark, M. S., Fitness, J., \& Brissette, I. (2003). Understanding people's perceptions of relationships is crucial to understanding their emotional lives. In G. J. O. Fletcher \& M. S. Clark (Eds.), Handbook of social psychology: Interpersonal processes (pp. 253-278). Oxford: Blackwell.

Clark, M. S., Pataki, S., \& Carver, V. (1996). Some thoughts and feelings on self-presentation of emotions in relationships. In G. J. O. Fletcher \& J. Fitness (Eds.), Knowledge structures in close relationships: A social psychological approach (pp. 247-274). New Jersey: 
Lawrence Erlbaum.

Clore, G. L., \& Ortony, A. (2010). Appraisal theories: How cognition shapes affects into emotion. In M. Lewins, J. M. Haviland-Jones and L. F. Barret (Eds.), Handbook of emotions (pp. 628-644). Yew York: Guilford.

Cohen, J. (1992). A power primer. Psychological Bulletin, 112, 155159. doi:10.1037/0033-2909.112.1.155

Collins, N. L., Ford, M. B., Guichard, A. C., \& Allard, L. M. (2006). Working models of attachment and attribution processes in intimate relationships. Personality and Social Psychology Bulletin, 32, 201219. doi:10.1177/0146167205280907

Diener, E. (1984). Subjective well-being. Psychological Bulletin, 96, 542-575. doi:10.1037/0033-2909.95.3.542

Diener, E. (2000). Subjective well-being. The science of happiness and a proposal for national index. American Psychologist, 55, 34-43. doi:10.1037/0003-066X.55.1.34

Diener, E., Lucas, R. E., \& Oishi, S. (2005). Subjective well-being: The science of happiness and life satisfaction. In C. R. Snyder and S. J. Lopez (Eds.), Handbook of positive psychology (pp. 63-73). Oxford: University Press.

Diener, E., \& Seligman, M. (2002). Very happy people. Psychological Science, 13, 81-84. doi:10.1111/1467-9280.00415

Dryfoos, J. G. (1998). Safe passages: Making it through adolescence in a risky society. Oxford: University Press.

Eccles, J. S., \& Wigfield, A. (2002). Motivational beliefs, values and goals. Annual Review of Psychology, 53, 109-132. doi:10.1146/annurev.psych.53.100901.135153

Efklides, A. (2001). Metacognitive experiences in problem solving: Metacognition, cognition and self regulation. In A. Efklides, J. Kuhl and R. M. Sorrrentino (Eds), Trends and prospects in motivation research (pp. 297-323). Dordrecht, The Netherands: Kluwer.

Erber, R., \& Gilmour, R (1995). Theoretical frameworks for personal relationships. Hillsdale, N.J.: Lawrence Erlbaum.

Fiedler, K., Semin, G. R., Finkenauer, D., \& Berkel, I. (1995). Actorobserver bias in close relationships. Personality and Social Psychology Bulletin, 21, 525-538. doi:10.1177/0146167295215010

Fincham, F. D. (2003). Attributions in close relationships: From balkanization to integration. In G. J. O. Fletcher \& M. S. Clark (Eds.), Handbook of social psychology: Interpersonal processes (pp. 3-31). Oxford: Blackwell.

Fincham, F. D., Beach, S. R., Arias, I., \& Brody, G. (1998). Children's attributions in the family: The children's relationship attribution measure. Journal of Family Psychology, 12, 481-493. doi:10.1037/0893-3200.12.4.481

Fitness, J., \& Fletcher, G. J. O. (1993). Love, hate, anger and jealousy in close relationships: A cognitive appraisal and prototype analysis. Journal of Personality and Social Psychology, 65, 942-958. doi:10.1037/0022-3514.65.5.942

Fitness, J., Fletcher, G. J. O., \& Overall, N. (2005). Interpersonal attraction and intimate relationships. In M. A. Hogg \& J. Cooper (Eds.), Handbook of social psychology (pp. 258-278). London: Sage.

Fletcher, G. J. O. (2002). The new science of intimate relationships. Oxford: Basil Blackwell. doi:10.1002/9780470773390

Fletcher, G. J. O., \& Clark, M. S. (2003). Introduction. In G. J. O., Fletcher \& M. S. Clark (Eds.), Handbook of social psychology: Interpersonal processes. Oxford: Blackwell.

Fletcher, G. J. O., Fitness, J., \& Blampied, N. M. (1990). The link between attributions and happiness in close relationships: The role of depression and explanatory style. Journal of Social and Clinical Psychology, 9, 243-255. doi:10.1521/jscp.1990.9.2.243

Fletcher, G. J. O., \& Thomas, G. (1996). Close relationship lay theories: Their structure and function. In G. J. O. Fletcher \& J. Fitness (Eds.), Knowledge structures in close relationships: A social psychological approach. New Jersey: Lawrence Erlbaum.

Fletcher, G. J. O., \& Thomas, G. (2000). Behavior and on-line cognition in marital interaction. Personal Relationships, 7, 111-130. doi:10.1111/j.1475-6811.2000.tb00007.x

Forgas, J. P. (1994). Sad and guilty? Affective influences on the explanation of conflict episodes. Journal of Personality and Social Psychology, 66, 56-68. doi:10.1037/0022-3514.66.1.56

Forgas, J. P. (1995). Mood and judgement: The affect infusion model (AIM). Psychological Bulletin, 117, 39-66.

doi:10.1037/0033-2909.117.1.39
Forgas, J. P. (2002). Feeling and doing: Affective influences on interpersonal behaviour. Psychological Inquiry, 13, 1-28. doi:10.1207/S15327965PLI1301 01

Forgas, J. P., \& Smith, C. A. (2005). Affect and Emotion. In M. A. Hogg and J. Cooper (Eds.), Handbook of social psychology (pp. 161189). London: Sage.

Frijda, N. H. (Ed.). (1993). Appraisal and beyond: Special issue of cognition and emotion. Hillsdale, NJ: Erlbaum.

Frijda, N. H. (2007). The laws of emotion. Mahwah: Erlbaum.

Frijda, N. H. (2009). Emotions, individual differences, and time course: Reflections. Cognition and Emotion, 23, 1444-1461. doi:10.1080/02699930903093276

Gifford-Smith, M. E., \& Brownell, C. A. (2003). Childhood peer relationship: social acceptance, friendships, and peer networks. Journal of School Psychology, 41, 235-284. doi:10.1016/S0022-4405(03)00048-7

Gilbert, D. T. \& Malone, P. S. (1995). The correspondence bias: The what, when, how and why of unwarranted dispositional inference. Psychological Bulletin, 111, 21-38. doi:10.1037/0033-2909.117.1.21

Gilham, J. (2000). The science of optimism and hope. Philadelphia, PA: Templeton Foundation Press.

Graham, S., \& Hoehn, S. (1995). Children's understanding of aggression and withdrawal as social stigmas: An attributional analysis. Child Development, 66, 1143-1161. doi:10.2307/1131804

Greitemeyer, T., \& Weiner, B. (2003). Asymmetrical attributions for approach versus avoidance behavior. Personality and Social Psychology Bulletin, 29, 1371-1382. doi:10.1177/0146167203255766

Harvey, J. H. (1987). Attributions in close relationships: Research and theoretical development. Journal of Social and Clinical Psychology, 5, 8-20. doi:10.1521/jscp. 1987.5.1.8

Harvey, J. H., \& Omarzu, J. (1999). Minding the close relationship. Personality and Social Psychology Review, 1, 223-239.

Harvey, J., Pauwels, B., \& Zickmund, S. (2005). Relationship connections: The role of minding in the enhancement of closeness. In C. R. Snyder and S. Lopez (Eds.), Handbook of positive psychology (pp. 423-434). Oxford: University Press.

Hewstone, M., \& Antaki, M. (2001). Attribution theory and social explanations. In M. Hewstone, W. Stroebe, J. P. Codol, and G. M. Stepheson (Eds.), Introduction to social psychology (pp. 111-141). Oxford: Basil Blackwell

Hoglund, W. L. G., Lalonde, C. E., \& Leadbeater, B. J. (2008). Socialcognitive competence, peer rejection and neglect, and behavioral and emotional problems in middle childhood, Social Development, 17, 528-553. doi:10.1111/j.1467-9507.2007.00449.x

Holder, M. D., \& Coleman, B. (2009). The contribution of social relationships to children's happiness. Journal of Happiness Studies, 10, 329-349. doi:10.1007/s10902-007-9083-0

Jaycox, L. I., Reivich, K. J., Gilhan, J., \& Seligman, M. E. P. (1994) Prevention of depressive symptoms in school children. Behavior Research and Therapy, 32, 801-816. doi:10.1016/0005-7967(94)90160-0

Jenkins, J. M., \& Ball, S. (2000). Distinguishing between negative emotions: children's understanding of the social-regulatory aspects of emotions. Cognition \& Emotion, 14, 261-282. doi:10.1080/026999300378969

Karney, B. R., McNulty, J. K., \& Bradbury, T. N. (2003). Cognition and the development of close relationships. In G. J. O. Fletcher \& M. S. Clark (Eds.), Handbook of social psychology: interpersonal processes (pp. 32-59). Oxford: Blackwell.

Keltner, D., Ellsworth, P. C., \& Edwards, K. (1993). Beyond simple pessimism: Effects of sadness and anger on social judgement. Journal of Personality and Social Psychology, 64, 740-752. doi: $10.1037 / 0022-3514.64 .5 .740$

Leary, M. R. (2000). Affect, cognition and the social emotions. In J. P. Forgas (Ed.), Feeling and thinking: The role of affect in social cognition (pp. 331-356). Cambridge: University Press.

Lewis, H. A., \& Kliewer, W. (1996). Hope, coping, and adjustment among children with sickle cell disease. Tests of mediator and moderator models. Journal of Pediatric Psychology, 21, 25-41. doi:10.1093/jpepsy/21.1.25

McAuley, E., Duncan, T. E., \& Russell, D. W. (1992). Measuring causal attributions: The revised Causal Dimension Scale (CDSII). Personality and Social Psychology Bulletin, 18, 566-573. 
doi: $10.1177 / 0146167292185006$

McDermott, D., \& Hastings, S. (2000). Children: Raising future hopes. In C. R. Snyder (Ed.), Handbook of hope: Theory, measures, and applications (pp. 185-199). San Diego, CA: Academic Press.

Myers, D. (2000). The funds, friends and faith of happy people. American Psychologist, 55, 56-67. doi:10.1037/0003-066X.55.1.56

Nolen-Hoeksema, S., \& Davis, C. G. (2005). Positive responses to loss: Perceiving benefits and growth. In C. R. Snyder and S. J. Lopez (Eds.), Handbook of positive psychology (pp. 598-607). Oxford: University Press.

Oatley, K. \& Jenkins, J. (1998). Understanding emotions. Cambridge: Blackwell.

Ortony, A., Clore, G. L., \& Collins, A. (1988). The cognitive structure of emotions. Cambridge: University Press. doi:10.1017/CBO9780511571299

Overwalle, F., Heylighen, F., Casaer, S., \& Daniels, M. (1992). Preattributional and attributional determinants of emotions and expectations. European Journal of Social Psychology, 22, 313-329. doi:10.1002/ejsp.2420220402

Parrott, W. G. (2003). The nature of emotions. In A. Tesser and N. Schwarz (Eds.), Handbook of social psychology: Intraindividual processes (pp. 375-390). Oxford: Blackwell.

Peterson, C. (2000). The future of optimism. American Psychologist, 55, 44-55. doi:10.1037/0003-066X.55.1.44

Peterson C., \& Steen, T. A. (2005). Optimistic explanatory style. In C. R. Snyder, and S. J. Lopez (Eds.), Handbook of positive psychology (pp. 244-256). Oxford: University Press

Planalp, S., \& Fitness, J. (1999). Thinking/feeling about personal and social relationships. Journal of Social and Personal Relationships, 16, 731-750. doi:10.1177/0265407599166004

Planalp, S., \& Rivers, M. (1996). Changes in knowledge of personal relationships. In G. J. O. Fletcher \& J. Fitness (Eds.), Knowledge structures in close relationships: A social psychological approach. NJ: Lawrence Erlbaum.

Prager, K. J. (1995). The psychology of intimacy. New York: Guilford.

Reis, H. T., \& Patrick, B. C. (1996). Attachement and intimacy: Component processes. In E. T. Higgins \& A. Kruklanski (Eds.), Social Psychology: Handbook of basic principles (pp. 523 -563). New York: Guilford.

Roberts, M. C., Brown, K. J., Johnson, R. J., \& Reinke, J. (2005). Positive psychology for children: Development, prevention, and promotion. In C. R. Snyder and S. J. Lopez (Eds.), Handbook of positive psychology (pp. 663-686). Oxford: University Press.

Rockhill, C. M., Fan, M.-Y., Katon, W. J., McCauley E., Crick, N. R., \& Pleck, J. H. (2007). Friendship interactions in children with and without depressive symptoms: observation of emotion during gameplaying interactions and post-game evaluations. Journal of Abnormal Child Psychology, 35, 429-441. doi:10.1007/s10802-007-9101-z

Rose, A. J. (2007). Structure, content, and socioemotional correlates of girls' and boys' friendships. Merrill-Palmer Quarterly, 53, 489-506. doi:10.1353/mpq.2007.0019

Ruehlman, L. S., \& Wolchik, S. A. (1988). Personal goals and interpersonal support and hindrance as factors in psychological distress and well-being. Journal of Personality and Social Psychology, 55, 293-301. doi:10.1037/0022-3514.55.2.293

Rusbult, C. E., Arriaga, X. B., \& Agnew, C. R. (2003). Interdependence in close relationships. In G. J. O. Fletcher and M. S. Clark (Eds.), Handbook of social psychology: Interpersonal processes (pp. 359387). Oxford: Blackwell.

Scheier, M., Carver, C., \& Bridges, M. (2000). Optimism, pessimism and psychological well-being. In E. Chang (Ed.), Optimism and pessimism: theory, research and practice. Washington, DC: American Psychological Association.

Seligman, M. E. P. (1991). Learned optimism. New York: Knopf.

Seligman, M. E. P. (2002). Authentic happiness: Using the new positive psychology to realise your potential for lasting fulfilment. New York: Free Press.

Seligman, M. E. P. (2005). Positive psychology, Positive prevention, and Positive therapy. In In C. R. Snyder and S. J. Lopez (Eds.), Handbook of positive psychology (pp. 3-9). Oxford: University Press.

Siegel, L. J. (1992). Overview. In A. M. La Greca, L. J. Siegel, J. L. Wallander and C. E. Walker (Eds.), Stress and coping in child health (pp. 3-6). New York: Guilford.
Siemer, M., Mauss I., \& Gross, J. (2007). Same situation-Different emotions: How appraisals shape our emotions. Emotion, 7, 592-600. doi:10.1037/1528-3542.7.3.592

Smith, C. A., \& Ellsworth, P. C. (1987). Patterns of appraisal and emotion related to taking an exam. Journal of Personality and Social Psychology, 52, 475-488. doi:10.1037/0022-3514.52.3.475

Smith, C. A., \& Lazarus, R. S. (1990). Emotions and adaptation. In L. A. Pervin (Ed.), Handbook of personality: Theory and research (pp. 609-637). New York: Guilford.

Smith, C. A., \& Kirby, L. D. (2000). Consequences require antecedents: Toward a process model of emotion elicitation. In J. Forgas (Ed.), Feeling and thinking: The role of affect in social cognition (pp. 83106). New York: Cambridge University Press.

Snyder, (1994). Hope and optimism. In V. S. Ramachandren (Ed.), Encyclopedia of human behaviour (pp. 535-542). San Diego, CA: Academic Press.

Snyder, C. R. (2000). Handbook of hope. Orlando FL: Academic press.

Snyder, C. R., Cheavens, J., \& Michael, S. T. (1999). Hoping. In C. R. Snyder (Ed.), Coping: The psychology of what works (pp. 205-231). New York: Oxford University Press.

Snyder, C. R., Cheavens, J., \& Sympson, S. C. (1997). Hope: An individual motive for social commerce. Group Dynamics: Theory, Research and Practice, 1, 107-118. doi:10.1037/1089-2699.1.2.107

Snyder, C. R., Feldman, D. B., Taylor, J. D., Schroeder, L. L., \& Adams, V. (2000). The roles of hopeful thinking in preventing problems and enhancing strengths. Applied and Preventive Psychology, 15, 262-295.

Snyder, C. R., Hoza, B., Pelham, W. E., Rapoff, M., Ware, L., Danovsky, M., Highberger, L., Rubinstein, H., \& Stahl, K. J. (1997). The development and validation of the Children's Hope Scale. Journal of Pediatric Psychology, 22, 399-421. doi:10.1093/jpepsy/22.3.399

Snyder, C. R., Irving, L., \& Anderson, J. R. (1991). Hope and health: Measuring the will and the ways. In C. R. Snyder and D. R. Forsyth (Eds.), Handbook of Social and clinical psychology: The health perspective (pp. 285-305). Elmsford, NY: Pergamon.

Snyder, C. R., McDermott, D., Cook, W., \& Rapoff, M. (1997). Hope for the journey: Helping children through the good time and the bad. San Francisco: HarperCollins.

Snyder, C. R., Rand, K. L. R, \& Sigmon, D. R. (2005). Hope theory. In C. R. Snyder and S. J. Lopez (Eds.), Handbook of positive psychology (pp. 257-276). Oxford: University Press.

Stephanou, G. (2004). School learning and achievement as social activities: The role of the interpersonal relationships and the subsequent emotions in academic achievement. In N. P. Terzis (Ed.), Proceedings of the 5th International Congress of Balkan Society for Pedagogy and Education: Quality in Education in the Balkans (pp. 195203). Thessaloniki: Kyriakidis Brothers.

Stephanou, G. (2005). Academic performance and interpersonal relationships [in Greek]. In F. Vlachos, F. Bonoti, P. Metallidou, I. Dermitzaki, \& A. Efklides (Eds.), Human behavior and learning. Scientific annals of the psychological society of northern Greece (pp. 201-228). Athens: Ellinika Grammata.

Stephanou, G. (2007). Students' appraisals and emotions for interpersonal relationships with teachers. In S. Vosniadou, D. Kayser and A. Protopapas (Eds.), Proceedings of the European Cognitive Science Conference (pp. 568-574). Canada: Lawrence Erlibaum Associates.

Stephanou, G. (2008). Students' value beliefs, performance expectations, and school performance: The effect of school subject and gender. Hellenic Journal of Psychology: The Journal of the Psychological Society of Northern Greece, 5, 231-257.

Stephanou, G. (2010, December). Children's hope, attributions and emotions for their friendships. In G. Stephanou, invited symposium Children and Youth interpersonal relationships: Socio-cognitive factors and emotional experience. 3rd International Conference of the Psychological Society of Northern Greece: Children and Youth in Changing Societies. Thessaloniki.

Stephanou, G., \& Balkamou, K. (2010, December). Elementary school children's attributions and emotions for their friendships with their peers. Paper presented at the $3 r d$ International Conference of the Psychological Society of Northern Greece: Children and Youth in Changing Societies. Thessaloniki.

Sympson, S. (1999). Validation of the domain specific hope scale. 
Unpublished doctoral dissertation, University of Kansas, Lawrence.

Taylor, S. E. (1989). Positive illusions: Creative self-deception and the healthy mind. New York: Basic Books.

Trope, Y., \& Gaunt, R. (2005). Attribution and person perception. In M. A. Hogg and J. Cooper (Eds.), Handbook of social psychology (pp. 190-208). London: Sage.

Underwood, M., \& Hurley, J., (1999). Emotion regulation and peer relationships during the middle childhood years. Child Development, 63, 366-380. doi:10.2307/1131485

Vandell, D. L., Nenide, L., \& Van Winkle, S. J. (2007). Peer relationships in early childhood. In K. McCartney and D. Phillips (Eds.), The Blackwell Handbook of early childhood development. New York: Blackwell.

Weiner, B. (1992). Human motivation: Metaphors, theories and research. London: Sage.

Weiner, B. (1995). Judgments of responsibility: A foundation for a theory of social conduct. New York: Guilford.

Weiner, B. (2001). Intrapersonal and interpersonal theories of motiva- tion from an attributional perspective. Educational Psychology Review, 12, 1-14. doi:10.1023/A:1009017532121

Weiner, B. (2002). Social emotions and personality inferences: A Scaffold for a new direction in the study of achievement motivation. 8th WATM \& Motivation and Emotion Conference, Moskow, Russia.

Weiner, B. (2005). Motivation from an attribution perspective and the social psychology of perceived competence. In A. J. Elliot and C. S. Dweck (Eds.), Handbook of Competence and Motivation (pp. 73-84). New York: Guilford.

Weiner, B. (2006). Social motivation, justice, and the moral emotions: An attributional approach. Mahwah, NJ: Erlbaum.

Williams, B., \& Gilmore, J. (2008). Annotation: Sociometry and peer relationships. Journal of Child Psychology and Psychiatric, 35, $997-$ 1013. doi:10.1111/j.1469-7610.1994.tb01806.x

Ybarra, O., \& Stephan, W. G. (1999). Attributional orientation and the prediction of behavior: The attribution-prediction bias. Journal of Personality and Social Psychology, 76, 718-727. doi: $10.1037 / 0022-3514.76 .5 .718$ 